\section{Questión}

Periodismo / Comunicación ISSN 1669-6581
- Av. $44 \mathrm{~N}^{\circ} 676,1^{\circ}$ piso

CP 1900 - La Plata - Argentina

www.perio.unlp.edu.ar/question

Pandemia: Radio Universidad de Comodoro Rivadavi decidió informar con prudencia.

Marcelo Sedrón - Carlos Milito

https://doi.org/10.24215/16696581e382

\title{
Pandemia: Radio Universidad de Comodoro Rivadavia decidió informar con prudencia
}

\section{Pandemic: Radio University of Comodoro Rivadavia decided to report cautiously}

\author{
Entrevista sonora a Marcelo Sedrón, Director de Radio Universidad de Comodoro Rivadavia \\ por Carlos Milito
}

\section{Resumen}

Durante la vigencia del aislamiento social preventivo y obligatorio dispuesto por el Gobierno Nacional Argentino a raíz de la pandemia, aparecieron nuevas modalidades en los consumos culturales, no obstante, la radio ha sido consecuente con su rol de informar e interpretar lo que sucede en una sociedad, acosada por el COVID-19. En este marco, las radios universitarias argentinas cumplen al informar con responsabilidad e interpretar lo que sucede. Cada una de las radios que integran ARUNA, la Asociación de Radios universitarias argentinas lo hace con su huella institucional y con la responsabilidad de ser un medio de comunicación Público. Marcelo Sedrón, explica que la pandemia altero la gestión de la emisora.

\section{Palabras Claves}

Radios Universitarias - Pandemia -Tecnologías - Estrategia - Infodemia - Periodismo - Gestión

\section{Summary}

During the term of the preventive and mandatory social isolation provided by the Argentine National Government following the pandemic, new modalities appeared in cultural consumption, however radio has been consistent with its role of informing and interpreting what happens in a 
society, harassed by COVID-19. In this context, the Argentine radios universitaries comply by reporting respaware and interpreting what happens. Each of the radios that make up ARUNA, the Argentine University Radios Association does so with its institutional footprint and with the responsibility of being a public media. Marcelo Sedrón, explains that the pandemic alters the management of the station.

\section{Keywords}

University Radios - Pandemic - Technologies - Strategy - Infodemia - Journalism -

\section{Management}

Marcelo Sedrón marcelosedron@hotmail.com Director, locutor y periodista de Radio Universidad de Comodoro Rivadavia, que pertenece a la Universidad Nacional

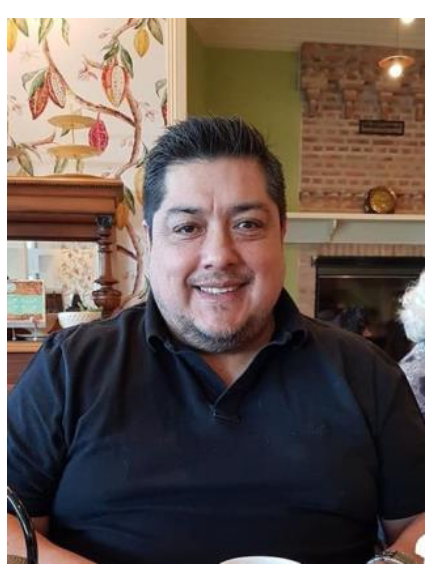
de Patagonia San Juan Bosco, en la provincia de Chubut.

\section{Entrevista}

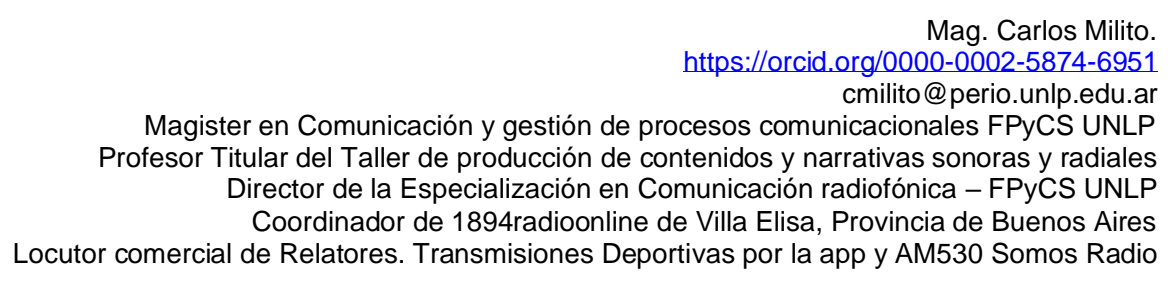

\section{Enlace}

https://ar.ivoox.com/es/51717964 